\title{
Lembranças da tempestade: passado, presente e futuro na construção de narrativas de memória sobre o Movimento dos Marinheiros (1962-1964) e a repressão em Rio Grande-RS \\ pg 34-57
}

Edgar Ávila Gandra ${ }^{1}$

Robert Wagner Porto da Silva Castro ${ }^{2}$

\section{Resumo}

O presente artigo constitui-se em uma releitura da mobilização da Associação de Marinheiros e Fuzileiros Navais do Brasil (AMFNB) e seus desdobramentos na cidade brasileira de Rio Grande-RS e tem como recorte de tempo o ano de 1964. Em específico abordamos a memória sobre o contexto da repressão conduzida pela Marinha do Brasil nessa cidade. Neste sentido, a memória da trajetória de alguns militares e ex-militares enquanto membros ou apoiadores da AMFNB foi elemento primordial para a construção desse trabalho. Destarte, o presente trabalho busca ainda contribuir para um melhor entendimento acerca do alcance do movimento dos marinheiros, bem como, da maneira como foi conduzida a repressão em Rio Grande-RS.

Palavras-chave: Memória, Marinheiros, Golpe Civil-Militar, Rio Grande-RS.

\section{MEMORIES OF THE STORM: PAST, PRESENT AND FUTURE IN THE CONSTRUCTION OF MEMORY NARRATIVES ABOUT THE SAILORS' MOVEMENT (1962-1964) AND REPRESSION IN RIO GRANDE-RS}

\begin{abstract}
This article is a re-reading of the mobilization of the Association of Mariners and Marine Corps of Brazil (AMFNB) and its developments in the Brazilian city of Rio Grande-RS and has as a cut of time the year of 1964. Specifically we approach the memory on the context of the repression conducted by the Brazilian Navy in that city. In this sense, the memory of the trajectory of some soldiers and exservicemen as members or supporters of the AMFNB was a primordial element for the construction of this work. Therefore, the present work seeks to contribute to a better understanding of the scope of the sailors' movement, as well as the way in which repression was conducted in Rio Grande-RS Keywords: Memory, Sailors, Civil-Military Coup, Rio Grande-RS.

1 Doutor em História pela UFRGS, Professor associado do Departamento de História e PPGH/UFPel e Professor colaborador do CITCEM da Universidade do Porto. E-mail: edgargandra@yahoo.com.br

2 Mestre em História pela UFPel e Doutorando do PPGH/PUC-RS. E-mail: robertporto63@gmail.com
\end{abstract}




\section{Introdução}

O presente artigo busca discutir o embate de memória na perspectiva da história do tempo presente. Para esse fim, analisamos a memória reavivada de marinheiros brasileiros - membros e apoiadores da Associação de Marinheiros e Fuzileiros Navais do Brasil (AMFNB) - sobre o cenário político de mobilizações da década de 1960 , em específico o advento do golpe civil-militar de 1964. Destacamos, de início, o desafio de analisar um segmento social vinculado a uma instituição total, que busca regrar a cotidianidade dos seus membros como é o caso de uma organização militar como a Marinha do Brasil. A memória reconstruída desses praças nas graduações iniciais ${ }^{3}$ da carreira militarnaval, doravante nominados marinheiros, torna-se um rico filão para análise frente a essa perspectiva na medida em que resistem a esse regramento e emergem em manifestações que contestam a trajetória que lhes era imposta. Também é digna de nota a reflexão sobre a sua importância para a constituição de identidades individuais e coletivas.

Dessarte, no âmbito da historiografia, a memória vem se tornando arcabouço de análises que buscam trazer à luz as perspectivas daqueles que não tiveram espaço na construção da "memória oficial" sobre determinados acontecimentos ou contextos históricos relacionados, principalmente, ao tempo presente. Isto é, aqueles que, em momentos tensionados da história, foram "vencidos" e, assim, acompanharam o propagar das ideias dos "vencedores" sem a oportunidade de se fazerem "ouvir" sobre as suas perspectivas acerca desses momentos. Assim, os marinheiros membros e/ou apoiadores da AMFNB - enquanto "vencidos" à época do golpe, permaneceram desse modo durante os embates de memória que se seguiram após o fim da ditadura. Haja vista que,

3 Aprendizes-marinheiros, grumetes, marinheiros, soldados e cabos. eram tidos como subversivos e indisciplinados pela alta oficialidade das Forças Armadas, e ainda, como movimento que justificou e precipitou o golpe, por grande parte da esquerda.

Nesse sentido, "ao propor que se adotasse a perspectiva dos vencidos, a história vista de baixo, traz-se ao centro da cena a experiência de grupos e camadas sociais antes ignorados" (LUCA, 2011, p.113). Desse modo, apresentam-se em disputa diferentes memórias sobre acontecimentos carregados de significado para determinados grupos sociais. De modo que, se existem memórias distintas em disputa, podemos considerar que são construídas a partir de referenciais diferentes e, portanto, se fundamentam em demandas e perspectivas também díspares. Esses parâmetros que pautam a construção das memórias são estabelecidos a partir de relações com o presente e o futuro, ou seja, segundo Fernando Catroga:

[...] seus nexos são urdidos por afinidades electivas (sic.) e estas determinam que cada presente construa a sua própria história dentro do horizonte de possibilidades que ele é, não só em função da onticidade (sic.) do que ocorreu, mas também das suas carências, necessidades e expectativas (CATROGA, 2001, p.22).

Dessa forma iremos estabelecer uma breve reflexão sobre o processo de construção das memórias, a partir dos tempos pretérito, presente e futuro; e da maneira como esse processo atua na formação e consolidação de fronteiras identitárias, em contextos de disputa de memórias acerca de instantes históricos tensionados. Desse modo, poderemos perceber a significância da memória para a análise histórica, especialmente aquela que se dedica ao tempo presente, em contextos marcados por tensões e traumas cujas disputas ainda estão em aberto. Sobre memória, existem inúmeras concepções, já que ela não se reduz ao simples ato de recordar.

Para Maurice Halbwachs (2003, p.39), a memória seria um processo coletivo fruto da 
interação individual com os outros (o fenômeno social), possibilitando, assim, que as pessoas se lembrem de determinados fatos. Deste modo, cria-se a concepção de uma memória coletiva que abrangeria toda uma influência da cultura social na sua formação. Faz sentido analisar o fato de que os indivíduos dialogam entre si, criando-se assim uma linha tênue entre diferença e identidade, formadores de memórias que são reflexos do fenômeno social. Nesse sentido, "ainda que só indivíduos possam recordar [...] a interiorização da alteridade permite detectar a existência de uma analogia entre estrutura subjetiva do tempo e a que passou a dar sentido à vida coletiva" (CATROGA, 2001, p.18). Ao passo que, segundo Kathryn Woodward (2014, p.13), a identidade de um determinado grupo é relacional, ou seja, constituise a partir da relação e da diferença relativa a outras identidades e também se vincula a aspectos e condições sociais e materiais. Dessarte, a memória - como instrumento de reconstrução da trajetória de determinados grupos não abarcados pela "memória oficial" - está intimamente relacionada com a ideia de cultura política. No sentido de "um fenômeno de múltiplos parâmetros, que não leva a uma explicação unívoca, mas permite adaptar-se à complexidade dos comportamentos humanos" (BERSTEIN, 1998, p.350).

O trabalho de releitura da trajetória de segmentos minoritários, marginalizados e/ou excluídos; a partir de suas memórias subterrâneas (POLLAK, 1989, p.4), torna possível compreender de modo mais aprofundado como determinados acontecimentos políticos ocorrem, e que só ocorrem a partir de pressões sociais. Entretanto, assim como os demais tipos de fontes com as quais o historiador trabalha, por força de seu ofício, a memória é dotada de determinado grau de subjetividade. Mas com a característica de ser "volátil" de acordo com as demandas do presente e perspectivas de futuro, ou, nas palavras de Fernando Catroga, "ela é a retenção afectiva (sic.) e "quente" dos "traços" inscritos na tensão tridimensional do tempo que permanentemente a tece" (CATROGA, 2001, p.20). Esta característica da memória não diminui sua relevância enquanto fonte a ser trabalhada pelos historiadores. Mas, no contexto de um passado "soterrado", deve-se ter o cuidado de não sobrepor a memória à história, entre as quais, no entender de Denise Rollemberg, existe um "abismo aprofundado com o tempo [...] num confronto em que os personagens e os testemunhos assumiram a missão de guardiães da memória, arautos da história" (ROLLEMBERG, 2009, p.378). Cabe sim ao historiador analisar a memória enquanto fonte, ciente de que, sobretudo nas "batalhas de memória", esta, "imersa no presente, preocupada com o futuro, quando suscitada, é sempre seletiva. Provocada, revela, mas também silencia.” (REIS, 2004, p.29).

\section{Marinheiros e a "Associação Fuzinauta" ${ }^{\prime 4}$}

As relações sociais estabelecidas nos mais diversos segmentos da sociedade podem ser reduzidas, grosso modo, a um constante processo de interação entre os atores sociais onde é possível verificar uma disputa de forças que resulta em relações de integração e/ou controle e resistência. Entretanto, alguns segmentos específicos apresentam características que tornam essas relações sociais significativamente mais complexas, como o caso dos marinheiros. Membros de um segmento das Forças Armadas, os marinheiros são militares que exercem uma atividade da qual são depositários de suas tradições e costumes. Atividade esta que os distingue significativamente dos demais integrantes das outras forças, tendo em vista o local onde a desempenham, ou seja, a bordo de navios de guerra. Espaço este que tem a característica 4 Termo empregado na Marinha para aludir aquilo que se refere a marinheiros e fuzileiros navais. 
de se constituir, de maneira simultânea, enquanto local de trabalho e moradia para esses militares, principalmente durante os longos períodos no mar. Tornando-se assim um microcosmo onde são estabelecidas relações sociais de diversas naturezas, especialmente relações de trabalho. Ou seja, podemos compreender os marinheiros - desde a formação e durante diversos momentos da carreira naval, especialmente quando embarcados a bordo dos navios - como, usando a expressão de Erving Goffman (1974), “internados de instituições totais", na medida em que:

Uma instituição total pode ser definida como um local de residência e trabalho onde um grande número de indivíduos com situação semelhante, separados da sociedade mais ampla por considerável período de tempo, levam uma vida fechada e formalmente administrada (GOFFMAN, 1974, p.11).

Desse modo, as relações estabelecidas entre oficiais e marinheiros tendem a se restringir aquilo a que se propõe o navio ou quartel, isto é, "realizar de modo mais adequado alguma tarefa de trabalho" (GOFFMAN, 1974, p.17). Neste sentido, no que concerne ao recorte temporal em tela, as relações estabelecidas entre marinheiros, oriundos das camadas menos favorecidas da sociedade, e uma oficialidade oriunda das camadas mais abastadas, tendiam a ser naturalmente tensas. $\mathrm{Na}$ medida em que existia, especialmente a bordo dos navios:

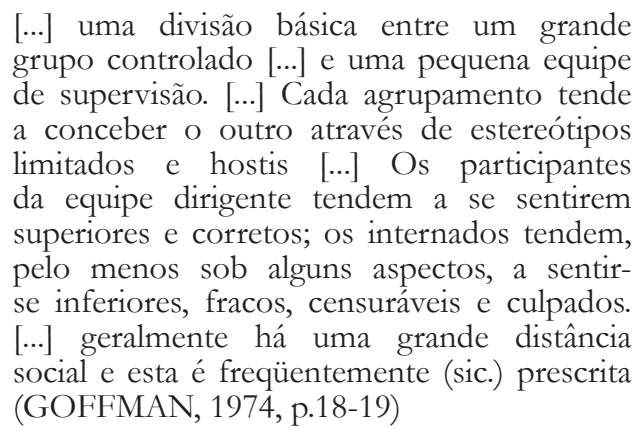

Destarte, submetidos a uma realidade em que a autoridade e a condição de "superioridade social" da oficialidade eram sempre reforçadas e reafirmadas através de tradições e regulamentos.
Fosse por intermédio de subterfúgios em suas rotinas, ou ainda, por meio de uma leitura própria do contexto político-social em que estavam inseridos e da realidade por eles experienciada na Marinha Brasileira. Os marinheiros buscaram maneiras de resistirem a esse controle, o qual se apresentava para além da hierarquia militar. Foi nesse contexto que se constituiu a AMFNB enquanto forma organizada de resistência no processo de disputa interna nos quadros da força naval. Buscando na associação uma forma de alcançar as respostas que esperavam da alta administração naval para suas demandas ${ }^{5}$, ou ao menos, obter apoio diante das dificuldades enfrentadas na força naval. Desse modo, podemos considerar que o processo de constituição da associação "fuzinauta" - fundada no dia 24 de março de 1962 com o principal objetivo de "manter seus associados unidos em torno de seus problemas, prestando assistências: social, cultural, desportiva, educacional a marinheiros e fuzileiros navais, associados, e, assistência geral a seus familiares" ${ }^{\prime 6}$ está diretamente relacionado a um sentimento de unidade e pertencimento por parte desses militares da Marinha Brasileira, bem como, à resistência a uma realidade na qual estavam inseridos.

Nesse sentido, nas palavras do ex-marinheiro Paulo Fernando da Costa ${ }^{7}$ :

[...] a associação pra (sic) quem queria algo diferente na Marinha, poder estudar [...] Só que as reivindicações, nós não podia (sic) andar civil na rua, era umas das reivindicações era andar civil. [...] você não podia casar, o pessoal não podia, era proibido casar. Então tinha uma série de reivindicações que a associação fazia. ${ }^{8}$

5 Entre as quais destacavam-se questões relativas a avanços em garantias sociais e direitos, além daquelas afetas especificamente às condições de trabalho a bordo, carreira e remuneração.

6 Base de dados do Projeto Brasil Nunca Mais - BNM 149, p. 2588 Primeira finalidade exposta no Art. $3^{\circ}$ do Estatuto da AMFNB.

7 Paulo Fernando Santos da Costa, gaúcho da cidade de Rio Grande-RS, ingressou na Marinha no ano de 1961 através da Escola de Aprendizes-Marinheiros de Santa Catarina, situada na cidade de Florianópolis. Foi integrante da AMFNB, sendo expulso da força naval após o golpe civil-militar em 1964. Após ingressar na justiça, alcançou a anistia e o direito de ser reformado pela Marinha.

8 Entrevista realizada por Edgar Ávila Gandra e Robert Wagner Porto da S. Castro, em 02 de novembro de 2013, na residência do entrevistado no bairro Cassino, cidade de Rio Grande-RS. 
E ainda, de acordo com José Xavier Cortez, ex-marinheiro e uma das lideranças da AMFNB:

Não fazia parte do nosso cotidiano, as festas. Nós não éramos convidados para nada. $\mathrm{O}$ nosso mundo se resumia àquele mundo da Marinha e nós achávamos que a Associação tinha a função de integrar o marinheiro à sociedade [...]. O objetivo da Associação era, também, quando nós chegássemos a um porto qualquer [...], no Recife, na Bahia ou em Porto Alegre, ter alguém da Associação que fosse capaz de fazer um jantar, convidar-nos para um almoço, ir a um baile à noite, nos divertir. Porque o lazer faz parte da vida das pessoas. Nós tínhamos direito ao lazer. Por que só os oficiais??

Em suas narrativas os ex-marinheiros Paulo Fernando da Costa e José Xavier Cortez evidenciam algumas das demandas daqueles militares, atinentes, sobretudo, a aspectos relacionados às garantias sociais e direitos. Existiam ainda, outras reivindicações mais específicas, ligadas à carreira, vencimentos e às condições de trabalho, especialmente a bordo dos navios.

Nesse cenário, em um contexto de acentuada luta política e mobilizações por parte das classes trabalhadoras do país, no qual se insere a radicalização do movimento dos marinheiros da AMFNB. Diante da recusa da cúpula naval brasileira em abrir negociação em torno das demandas apresentadas pelos marinheiros, sobre as quais já tinham conhecimento, pelo menos, desde a fundação da associação "fuzinauta". Esses militares, com base na leitura do contexto políticosocial vigente, passaram a integrar a cena política nacional. E, juntamente com diversas entidades sindicais e de representação de categorias e segmentos da sociedade brasileira, expressaram apoio ao projeto reformista do então presidente João Goulart. Posicionamento que aprofundou ainda mais a crise na Marinha, a qual teve seu ponto na assembleia comemorativa pelo segundo aniversário da associação, realizada no dia 25 de março de 1964 no Sindicato dos Metalúrgicos da

9 Entrevista concedida a Anderson da Silva Almeida em 22dez.2009. Apud ALMEIDA, 2010, p.40.
Guanabara-RJ ${ }^{10}$. Ocasião em que, após notícias sobre prisões de membros da associação, um evento de cunho comemorativo se converteu em ato permanente.

Neste contexto, o "Palácio de Aço"l1 tornou-se palco público para as reivindicações dos marinheiros e fuzileiros, muitos dos quais ao saberem dos acontecimentos dirigiram-se para o sindicato a fim de apoiar seus companheiros. Neste momento ocorreram enfrentamentos, especialmente na área do Ministério da Marinha e a bordo de alguns navios - na zona portuária da cidade do Rio de Janeiro-RJ. Houve atos de sabotagem em alguns navios para impedir que se fizessem ao mar ou reduzir sua capacidade de combate, como nos casos do navio José Bonifácio e do Aviso Oceânico Bauru, respectivamente. No contratorpedeiro Pernambuco ${ }^{12}$ ocorreu atos de insubordinação, tentativa de invasão do navio por militares do contratorpedeiro Paraíba que estava atracado a contrabordo ${ }^{13}$ e enfrentamento entre oficiais e marinheiros.

Em terra a situação também ficou tensa, tendo ocorrido, talvez, o episódio mais violento de toda mobilização dos marinheiros. Ao tentar cruzar a ponte que liga a Ilha das Cobras ${ }^{14}$ ao continente, um grupo de marinheiros que havia saído dos navios com o objetivo de seguir para o sindicato, foi alvejado por disparos vindos do prédio principal do Ministério da Marinha. Alguns militares ficaram feridos e outros se lançaram na água com o intuito de escaparem dos disparos, mas a grande maioria regressou para seus navios, tendo alguns 10 Situado no bairro de São Cristóvão, região central da cidade do Rio de Janeiro-RJ.

11 Denominação conferida ao Sindicato dos Metalúrgicos do Estado da Guanabara situado no bairro de São Cristóvão, zona norte da cidade do Rio de Janeiro, nas proximidades da região central da cidade.

12 BNM 506, p.523 e 578.

13 Termo que significa que um navio ou embarcação está "ao lado" de outro,

14 Ilha situada na região do antigo Ministério da Marinha, atual Comando do $1^{\circ}$ Distrito Naval, onde está instalado o AMRJ e onde ficam atracados parte dos navios da Marinha do Brasil. 
sido presos de imediato. Em seu depoimento ${ }^{15} \mathrm{O}$ soldado Osiel Costa de Araujo relata que o grupo de marinheiros e fuzileiros vinha caminhando do interior do AMRJ e cantando o Hino Nacional e que ao sentir o ferimento em sua perna logo ouviu disparos. Ficando imobilizado devido ao ferimento foi logo preso por um oficial e em seguida conduzido ao pronto socorro. No Inquérito Policial Militar (IPM) instaurado para averiguar o ocorrido, consta uma relação com os nomes de onze praças presos na ocasião - entre marujos e fuzileiros inclusive o soldado Osiel, que era também sócio da AMFNB. Esta relação é anexa a um ofício onde o comandante do $1^{\circ}$ Distrito Naval relata o ocorrido ao Chefe do Estado-Maior da Armada, e informa sobre os três militares que teriam ficado feridos "sem gravidade devido a terem ricocheteado os projetis (sic) disparados".

Concomitantemente, sucediam-se discursos inflamados na sede do sindicato dos metalúrgicos, onde o então presidente da AMFNB - marinheiro de primeira-classe José Anselmo dos Santos ${ }^{16}$ na presença emblemática do ícone da Revolta da Chibata, o "Almirante Negro" João Cândido, declarava apoio ao presidente Goulart e ao seu projeto reformista. Demonstrando ainda, alinhamento às pautas defendidas pelos segmentos sociais e categorias que apoiavam João Goulart.

Aceite senhor presidente, a saudação de marinheiros e fuzileiros navais do Brasil, que são filhos e irmãos dos operários, dos camponeses, dos estudantes, das donasde-casa (sic.), dos intelectuais e dos oficiais progressistas das nossas Forças Armadas. [...] Aceite senhor presidente, a saudação do povo fardado que, com ansiedade, espera a realização efetiva das Reformas de Base (sic.) que libertarão da miséria os explorados do campo e da cidade, dos navios e dos quartéis. A Associação de Marinheiros e Fuzileiros Navais do Brasil completa, neste mês de março, o seu segundo aniversário. E foram condições históricas, a fome, as discriminações, os anseios de Liberdade (sic.), as perseguições

15 BNM 045, p. 159-161 - Depoimento do soldado Osiel Costa de Araujo.

16 Conhecido como "cabo" Anselmo, foi eleito presidente da AMFNB em dezembro de 1962, nas eleições que elegeram sua segunda diretoria. e as injustiças sofridas que determinaram a criação de uma sociedade civil, realmente independente, com a finalidade de unir, através da educação, da cultura e da recreação marinheiros e fuzileiros navais do Brasil. [...] Autoridades reacionárias, aliadas ao antipovo (sic.) e escudadas nos regulamentos arcaicos e em decretos institucionais, qualificam de entidade subversiva. Será subversivo manter cursos para marinheiros? Será subversivo dar assistência médica e jurídica? Será subversivo visitar a Petrobrás? Será subversivo convidar o Presidente da República para dialogar com o povo fardado? ${ }^{17}$

Neste sentido, a partir do discurso de Anselmo e dos pronunciamentos de outras lideranças, a mobilização no "Palácio de Aço" ganhou contornos de uma grave crise institucional na força naval brasileira. Nesse cenário, o Ministro da Marinha determinou ao vice-almirante Cândido da Costa Aragão ${ }^{18}$ que um destacamento de fuzileiros fosse enviado ao sindicato para colocar fim à assembleia. Ao alegar não poder cumprir aquela ordem, Aragão pediu exoneração do cargo e foi afastado de suas funções. Um grupo de fuzileiros foi enviado, conforme determinado pelo almirante Sylvio Motta, mas ao chegarem à frente do sindicato vinte e seis daqueles militares depuseram suas armas e entraram no sindicato, juntando-se às centenas de marinheiros e fuzileiros ali reunidos.

Dessa forma, ainda no dia 26, tropas do $1^{\circ}$ Batalhão de Guardas do Exército Brasileiro ${ }^{19}$ foram enviadas para garantir a integridade física dos militares e civis reunidos naquele local. Diante da situação e da escalada da crise com os marinheiros, o Conselho do Almirantado ${ }^{20}$ sugeriu, através de um manifesto ao Ministro da Marinha, que fossem adotadas "providências para a detenção imediata 17 Discurso publicado no jornal Tribuna da Imprensa, 26mar.1964, p.8.

18 Comandante Geral do Corpo de Fuzileiros Navais, Cândido da Costa Aragão iniciou sua carreira na Marinha como soldado. Era simpático ao movimento da AMFNB e às propostas do presidente Goulart.

19 Unidade militar do Exército situada também no bairro de São Cristóvão, na cidade do Rio de Janeiro-RJ.

20 De acordo com o Art. $1^{\circ}$ do Decreto no 22070 de 10 de novembro de 1932; este é um órgão consultivo da administração naval brasileira para o estudo de problemas técnicos e administrativos que não sejam de caráter privativo do Ministro da Marinha. 
de todos os amotinados, para competente apuração de responsabilidades" (RODRIGUES, 2004, p.114). O almirante Sylvio Motta manteve o afastamento do vice-almirante Candido Aragão e em seguida solicitou ao presidente sua exoneração do cargo. No gozo de uma prerrogativa que lhe assistia enquanto comandante das Forças Armadas, João Goulart exonerou Sylvio Motta e nomeou o almirante de esquadra da reserva Paulo Mario da Cunha Rodrigues para a pasta do Ministério da Marinha. Titular de uma vaga como juiz no Tribunal Marítimo e oficial tido como nacionalista e simpático às causas dos marinheiros, Paulo Mario atuou no sentido de debelar a crise que se instaurara na força naval. $\mathrm{O}$ novo ministro determinou que os militares reunidos no sindicato fossem levados para o $1^{\circ}$ Batalhão de Guardas do Exército e lá permanecessem presos até ordem em contrário. Paulo Mario tomou uma série de medidas que descontentaram profundamente o Almirantado, entre as quais destacam-se a anistia a todos os marinheiros e fuzileiros envolvidos nos episódios do "Palácio de Aço", a recondução de Aragão ao comando geral dos fuzileiros e a nomeação do almirante de esquadra Pedro Paulo de Araújo Suzano para o cargo de chefe do EstadoMaior da Armada.

Ao tomar conhecimento das decisões do almirante Paulo Mário, o Conselho do Almirantado iniciou uma feroz ofensiva contra o mesmo e também contra o próprio presidente João Goulart. Juntamente com o Clube Naval, passou a emitir uma série de notas e manifestos ao Ministro da Marinha. No mais contundente dos manifestos, denominado À Nação, ao Congresso Nacional, às Assembleias, aos governadores, aos chefes militares e a todos os cidadãos ${ }^{21}$ a cúpula da Marinha fazia abertas críticas aos atos do ministro Paulo Mario e do próprio presidente Goulart. Conclamando a Nação para se defender da ameaça de comunização do país. Logo o Clube Militar e o da Aeronáutica se solidarizaram ao posicionamento dos almirantes do Clube Naval e do Conselho do Almirantado. Havia sido lançado o sinal para o golpe que se consumaria no primeiro dia de abril de 1964, culminando na extinção da AMFNB e intensa repressão sobre seus integrantes e apoiadores.

Destarte, os fatos ocorridos, tanto nos navios quanto nos quartéis da Marinha e no próprio Sindicato dos Metalúrgicos da Guanabara-RJ - a partir do dia 25 de março - denotam um acirramento definitivo das tensões entre o alto comando naval e o movimento "fuzinauta". Que se evidenciou no momento em que emergiram as disputas - a muito estabelecidas - entre oficiais e praças, no contexto de uma rotina marcada por relações de dominação e resistência. Denotando também a significativa identificação alcançada por marinheiros e fuzileiros em torno de sua associação, e ainda, a capacidade de mobilização daqueles militares na busca pelo atendimento de suas demandas e a postura absolutamente pacífica de seu movimento. Ao passo que, mesmo possuindo o conhecimento e a capacidade para pegarem em armas, optaram pela via pacífica diante das pressões e truculência da administração naval brasileira.

Após historiar brevemente sobre o processo de radicalização do movimento "fuzinauta" e, consequentemente, sobre o aprofundamento da crise nos quadros da Marinha, no contexto tensionado dos anos iniciais da década de 1960. Passaremos agora a buscar uma melhor compreensão sobre o modo como esses acontecimentos e a consequente repressão sobre esses marinheiros, especialmente na cidade de Rio Grande-RS, se apresentam em suas construções de memória. E ainda, de que modo essas memórias se apresentam no processo de construção da identidade dos mesmos enquanto marinheiros.

21 O Globo, 30 mar.1964, p.22. 


\section{"Operação Limpeza" e a "Cidade Vermelha"}

Após a onda de prisões desencadeadas pela "operação limpeza", tanto no meio civil quanto nos quadros da Marinha, muitos militares - especialmente praças nas graduações iniciais das Forças Armadas - tiveram que enfrentar as consequências administrativas de terem manifestado apoio ao presidente deposto. $\mathrm{Na}$ Marinha de Guerra o alvo eram as lideranças, membros e apoiadores da AMFNB. Muitos destes militares foram presos ainda no dia 3 de abril, quando o então Ministro da Marinha, almirante Augusto Hamann Rademaker Grunewald, determinou instauração de IPM para apuração dos fatos ocorridos no Sindicato dos Metalúrgicos da Guanabara-RJ entre os dias 26 e 27 de março de 1964. Algumas lideranças do movimento "fuzinauta" fugiram a fim de buscar apoio para uma possível resistência ao golpe. Mas a maioria absoluta daqueles militares regressou às suas unidades acreditando que seriam punidos disciplinarmente ou submetidos aos devidos processos administrativos para apuração das responsabilidades, conforme assegurado pelos regulamentos navais. Porém, já nos primeiros dias do mês de abril, estava em curso na Marinha um "expurgo" que "lançaria pela borda" centenas de militares, na maioria absoluta cabos, soldados e marinheiros. Findando com suas carreiras e levando ainda outros tantos à prisão. Ao passo que, ainda no ano de 1964 foram "expurgados" da força naval centenas de praças ${ }^{22}$, entre expulsões e demissões compulsórias.

No que concerne à cidade gaúcha de Rio Grande-RS, paradoxalmente à sua pouca notoriedade perante o senso comum da sociedade

22 Arquivo da União dos Militares Não Anistiados (UMNA) - Situação dos ex-militares punidos por motivação política por atos de exceção; Porto Alegre 28 ago.1989. brasileira, a urbe riograndina teve destacada importância no cenário político-econômico, não apenas do estado gaúcho, mas a nível nacional. Isto devido ao reconhecido histórico de atividades industriais exercidas na cidade, que contribuiu sobremaneira para o desenvolvimento de uma forte tradição sindical. E, principalmente, por situar-se naquela cidade o único porto oceânico do estado do Rio Grande do Sul e um dos maiores do país. Esta relevância da urbe riograndina, especialmente no contexto do golpe de 1964, fica evidente quando percebemos o modo e a intensidade com que atuou a repressão na cidade:

A repressão aos inimigos da denominada revolução não foi mais branda que em outras localidades. Em Rio Grande, várias pessoas foram presas, entre elas os principais dirigentes do Sindicato dos Trabalhadores nos Serviços Portuários de Rio Grande. O município só perdia em número de encarcerados para a capital gaúcha (GANDRA, 1999, p.90, grifo nosso).

O fato de a Marinha ter sido incumbida de capitanear as ações no sentido de assegurar a efetivação do golpe em Rio Grande-RS, deveu-se não somente a ser esta a arma de maior representatividade na cidade, cuja maior autoridade militar era o capitão de mar e guerra Mário Rodrigues da Costa, titular da principal organização militar-naval no estado gaúcho, a Capitania dos Portos do Rio Grande do Sul (CPRS). Mas, a despeito de se tratar de uma localidade de grande importância estratégica e econômica, ligada essencialmente às atividades marítimas, os segmentos de trabalhadores portuários, marítimos e marinheiros eram marginalizados, assim como a própria região onde se situa o porto e os seus locais de moradia. Tal situação demandou forte atuação repressiva da Marinha, sobretudo pela relevância do Sindicato dos Trabalhadores nos Serviços Portuários de Rio Grande-RS e sua atuação na cidade junto a outras categorias, especialmente; estivadores, portuários e marítimos. 
Destarte, estes segmentos de profissionais que compartilhavam o porto enquanto espaço de trabalho, estabeleciam pontos de contato não somente no locus portuário, mas, sobretudo em seus locais de moradia e diversão. Era comum frequentarem bares e baixos meretrícios localizados na zona portuária, bem como, estabelecerem residência nos bairros Getúlio Vargas e Santa Tereza, ambos situados nas imediações do porto. Deste modo, categorias como estivadores, marítimos e portuários da cidade de Rio Grande-RS mantinham entre si uma "perigosa proximidade", especialmente no contexto político social tensionado vigente no país à época, marcado por significativa efervescência popular em torno de reivindicações por garantias e avanços sociais para os segmentos trabalhadores. Neste contexto, a crescente mobilização em âmbito nacional de marinheiros e fuzileiros da força naval brasileira em torno de suas demandas ${ }^{23}$, associada a forte tradição marítima e sindical que renderam à urbe riograndina o apelido de "cidade vermelha". Levou o alto comando da Marinha a empreender esforços para a repressão naquela cidade desde os primeiros dias de abril de 1964. Instante este em que o chamado comando da revolução ainda não contava com o apoio definitivo do $3^{\circ}$ Exército e das forças policiais no Rio Grande do Sul.

No contexto da "tempestade" que se abateu sobre marinheiros e fuzileiros navais imediatamente após o golpe, a primeira atitude da alta administração naval no sentido de punir aqueles militares foi lançá-los "pela borda", isto é, 23 Através da Associação de Marinheiros e Fuzileiros Navais do Brasil (AMFNB), entidade fundada em 1962 e dissolvida definitivamente em novembro de 1964, militares nas graduações iniciais (cabos, marinheiros e soldados) da Marinha do Brasil reivindicavam junto a alta administração naval, principalmente questões afetas à carreira, garantias e avanços sociais; além de melhorias salariais e nas condições de trabalho. No contexto do crescente acirramento da cena política nacional, especialmente a partir de 1963, e ainda, diante do não atendimento de suas demandas por parte da cúpula naval, a AMFNB passou a dirigir suas reivindicações diretamente ao Presidente João Goulart, além de manifestar publicamente $\mathrm{O}$ apoio ao seu projeto reformista. Vide: ALMEIDA, 2010 e CASTRO, 2016. excluí-los da Marinha, realizando assim o expurgo nas fileiras navais. Neste sentido, passaremos a analisar a maneira e a intensidade como se deu a "operação limpeza" sobre membros e lideranças da AMFNB, especialmente sobre aqueles militares que, de algum modo, mantinham relações na cidade de Rio Grande-RS. Na medida em que, com base na precariedade de suas carreiras, já que a estabilidade era assegurada somente para as graduações de terceiro-sargento em diante, muitos foram sumariamente expulsos ou compulsoriamente licenciados do serviço ativo da Marinha.

O primeiro passo oficialmente dado pela administração naval para iniciar a caçada àqueles os quais julgava "prejudiciais à ordem pública e à disciplina militar," ${ }^{24}$ foi a publicação de três portarias do Ministro da Marinha. Nas quais determinava a instauração de IPM's a fim de apurar as responsabilidades, de oficiais e praças, nos acontecimentos havidos a partir do dia 26 de março. Foi nesta data que se deu a determinação de prontidão rigorosa na Marinha, portanto, somente a partir desta ordem é que os militares presentes no Sindicato dos Metalúrgicos da Guanabara-RJ estariam, de fato, incorrendo no crime de motim ${ }^{25}$.

Deste modo, através das portarias de números $0540^{26}$ e $0541^{27}$ o almirante Augusto Rademaker determinava, respectivamente, a apuração das responsabilidades dos envolvidos no ocorrido na assembleia da AMFNB e nas ocorrências a bordo dos navios e estabelecimentos de terra. Já através da portaria $0542^{28}$, foi determinada a apuração das "responsabilidades relacionadas com a conduta de oficiais que, de qualquer forma,

24 Expressão presente nos atos administrativos do Ministro da Marinha nos quais o mesmo resolvia expulsar centenas de praças, em virtude do que teria sido apurado pelos IPM's por ele mandados proceder através das portarias $n^{\circ} 0540,0541$ e 0542 em 3 de abril de 1964.

25 Art. 130 do CPM.

26 BNM 149, p.27.

27 BNM 045, p.16.

28 BNM 028, p.4. 
contribuíram com a crise de disciplina verificada a partir da madrugada de 26 de março." ${ }^{29}$ Não obstante as determinações exaradas através destes três documentos administrativos, consideramos que, por si só, já representavam o sinal para que se iniciasse a "limpa" nas fileiras da Marinha. Pois, independentemente das responsabilidades que fossem observadas, aqueles que de algum modo estiveram envolvidos com a mobilização da AMFNB deveriam ser rapidamente retirados do convívio dos demais militares. A fim de que fosse possível evitar novas mobilizações, bem como, demonstrar para o restante da tropa que a disciplina seria "reestabelecida" na Armada e no Corpo de Fuzileiros Navais. Reforçando assim a autoridade da oficialidade sobre os subalternos na força naval.

Neste cenário, entre os meses de abril de 1964 e fevereiro de 1965, foram publicados pelo Ministério da Marinha, treze atos de expulsão e punitivos (demissão compulsória) excluindo um total de $1509^{30}$ praças, entre os quais estavam as principais lideranças da AMFNB. Esta ação imediata da alta administração naval tinha como principais objetivos desmobilizar a cúpula da associação "fuzinauta" em nível nacional, e ainda, exercer papel pedagógico e disciplinar junto aos seus milhares de associados por todo país. Ao passo que seria operacionalmente inviável expulsar os mais de quatro mil militares associados.

Neste sentido, já no dia $1^{\circ}$ de maio, através do ato de expulsão $n^{\circ} 155^{31}$, foram excluídos da Marinha os primeiros dezoito subalternos. Entre os quais destacamos o marinheiro José Anselmo dos Santos - o "cabo" Anselmo - e o cabo João

29 BNM 028, p.4.

30 Arquivo da União dos Militares Não Anistiados (UMNA) - Situação dos ex-militares punidos por motivação política por atos de exceção; Porto Alegre 28ago.1989. Neste relatório constam os documentos administrativos do Ministério da Marinha que excluíram sumariamente os referidos praças dos quadros da força naval.

31 Arquivo da União dos Militares Não Anistiados (UMNA) - Boletim da Marinha $n^{\circ} 18$ de $1^{\circ}$ de maio de 1964, e fundamentado no Art. 103 alínea "f" do Decreto no 44.061 de 23 de julho de 1958.
Barbosa de Almeida, presidente e ex-presidente da associação "fuzinauta", respectivamente. Além de outros destacados integrantes da diretoria, como: os irmãos Josée Antônio Duarte dos Santos, Raul Alves do Nascimento Filho e o gaúcho Avelino Capitani, que ocupava o cargo de segundo vice-presidente da associação e era liderança atuante da AMFNB. Muitos destes militares, por sua liderança e atuação na diretoria da associação "fuzinauta", já tinham suas prisões decretadas pela força naval desde as vésperas da assembleia do dia 25 de março. Deste modo, tanto as punições disciplinares aplicadas aqueles subalternos às vésperas do golpe, quanto o processo sumário de expulsão e/ou demissão compulsória ao qual foram submetidos, foram instrumentos para a desmobilização e a coação da associação e seus membros, respectivamente.

Esta "ferramenta" foi largamente empregada em Rio Grande-RS através da prisão de suas reais e potenciais lideranças presentes na cidade, como o cabo Domingos Pereira e o capitão-tenente Aldo Lapolli, nesta ordem. Bem como, sobre aqueles militares que, enquanto membros da AMFNB, por questões familiares mantinham relações permanentes na zona sul gaúcha, em especial na urbe riograndina. Indicando assim uma preocupação da alta oficialidade da Marinha em "limpar" a cidade de Rio Grande-RS de toda e qualquer ameaça de subversão, seja ela no meio civil ou militar.

Destarte, analisando primeiramente a repressão que se abateu sobre os subalternos que - na condição de associados e lideranças da AMFNB, naturais de Rio Grande-RS e adjacências - encontravam-se lotados nas unidades navais sediadas na cidade do Rio de Janeiro-RJ. Percebemos que muitos daqueles militares, mesmo sem comprovada participação ou devida apuração das suas responsabilidades nos acontecimentos ocorridos a partir do dia 26 de março, foram sumariamente expulsos da Marinha. De maneira que, foi com base em denúncias de 
outros militares e "informes" de seus comandantes acerca de suas atividades "subversivas", que muitos daqueles subalternos tiveram apontadas as suas responsabilidades e, deste modo, tiveram suas carreiras abruptamente interrompidas ainda no ano de 1964.

Neste enredo, o então cabo Guillem Rodrigues da Silva, foi submetido ao IPMinstaurado para apurar as responsabilidades nas ocorrências verificadas a bordo do navio aviso oceanográfico (AvOc) Bauru, no contexto dos desdobramentos da mobilização da associação fuzinauta em fins do mês de março de 1964. Guillem Rodrigues, natural de Rio Grande-RS e membro da AMFNB, ao final do devido IPM foi denunciado à justiça militar como incurso no crime de motim, previsto no artigo 130 do CPM, bem como, nos crimes associados ao de motim previstos nos artigos 131 e 132 do mesmo código. $\mathrm{Na}$ referida acusação junto ao Conselho Permanente de Justiça da $1^{\mathrm{a}}$ Auditoria da Marinha consta o seguinte acerca de Guillem Rodrigues da Silva e outros acusados:

[...] praticaram os delitos em que foram enquadrados, através a (sic.) prática de numerosos e sucessivos atos de amotinação e revolta contra autoridades navais, especialmente no âmbito do navio em que serviam, ou seja (sic.) o AvOc "Bauru", organizando-se em grupos de cinco elementos que tinham a missão de controlar as atividades do navio e ocupá-lo, recorrendo inclusive à violência e chegando até à prática do crime de morte contra oficiais e subalternos que com eles não concordassem. ${ }^{32}$

Apesar da gravidade das acusações, Guilem Rodrigues foi absolvido ${ }^{33}$, por falta de provas, pelo Conselho Permanente da $1^{\text {a }}$ Auditoria em outubro de 1967. Sendo condenado ${ }^{34}$ a três anos e um mês de prisão, pelo crime previsto no artigo 132 combinado com o artigo 57 do CPM, somente por ocasião do recurso ${ }^{35}$ da procuradoria da referida auditoria ao Superior Tribunal Militar, em maio de

32 BNM 138, p.1077.

33 BNM 138, p.1087.

34 BNM 138, p.1129.

35 BNM 138, p.1119-1130.
1968. Apesar de penalmente condenado somente em 1968, Guillem Rodrigues foi expulso da Marinha ainda em dezembro de 1964, por "ter se tornado prejudicial à ordem pública e à disciplina militar. ${ }^{36 "}$

De modo semelhante, o então marinheiro de segunda classe Paulo Fernando Santos da Costa foi considerado como "elemento insubordinado e irrecuperável ${ }^{37 ",}$ e ainda, "ostensivamente ligado à situação deposta. ${ }^{38}$ " Desta maneira, mesmo sem ter participado da assembleia do dia 25 de março no "Palácio de Aço", e ainda, sem qualquer comprovação de que o mesmo estivera envolvido no episódio de insubordinação ocorrido a bordo do Tamandaré no dia 27 de março ${ }^{39}$, Paulo foi indiciado e sumariamente expulso das fileiras da Marinha sob a mesma alegação e através do mesmo ato que também “expurgou” seu conterrâneo Guillem Rodrigues.

Cabe ressaltar o posicionamento de parte da oficialidade naval naquele contexto, indicando a intenção em, de fato, "limpar" os quadros de subalternos da Marinha. O que fica evidente quando o comandante do cruzador Tamandaré, capitão de mar e guerra Orlando Ferreira da Costa, afirmou em um ofício destinado ao Chefe do Estado-Maior da Armada, referindo-se a 31 cabos e marinheiros, o seguinte:

[...] Os marinheiros abaixo relacionados pelas informacões de seus encarregados de divisão foram desembarcados no dia 3/4/64 por não inspirarem confiança e serem suspeitos de pela conduta anterior, provocarem atos de sabotagem ou criarem a bordo clima de intranquilidade entre a própria guarnição.

36 Arquivo da União dos Militares Não Anistiados (UMNA) - Conforme Ato $\mathrm{n}^{\circ} 425$ de 30 de novembro de 1964, publicado no Boletim do Ministério da Marinha no 50, de 11 de dezembro de 1964, e fundamentado no Art. 103 alínea "f" do Decreto n 44.061 de 23 de julho de 1958.

37 BNM 639, p. 100 - Elementos de informação, anexo ao ofício n ${ }^{\circ} 447$ de 24 de abril de 1964 do cruzador Tamandaré. 38 BNM 639, p. 619 - Relação anexa ao ofício no 503 de 6 de julho de 1964 do Comando da Força de Cruzadores e Contratorpedeiros.

39 BNM 639, p.295 - Termo de inquirição de indiciado em IPM instaurado por portaria de 13 de abril de 1964 do cruzador Tamandaré a fim de apurar "atos de indisciplina" ocorridos no dia 27 de março do mesmo ano a bordo daquele navio, conforme determinou o Chefe do Estado-Maior da Armada através do Boletim de Ordens e Notícias no 84 de 10 de abril de 1964 (BNM 639, p.19). 
A Marinha nada perderia com a sua exclusão sumária, mesmo que nenbum fato concreto, que os enquadre nos códigos ou regulamentos militares, possa ser apontado individualmente ${ }^{40}$ (Grifo nosso).

Neste mesmo ofício, no qual o supramencionado oficial aponta supostas "condutas subversivas" das principais lideranças da mobilização dos marinheiros a bordo do cruzador Tamandaré, entre as quais figura Paulo Costa. Consta também que a maioria daqueles militares "desembarcou" para o Quartel de Marinheiros ${ }^{41}$ (QM) ainda no dia 3 de abril, data das portarias do Ministro da Marinha mencionadas anteriormente. $\mathrm{O}$ que vem reforçar a ideia de que aquela unidade da Marinha foi utilizada como "boia" ${ }^{42}$ para aqueles militares que, por seus posicionamentos políticos e envolvimento com a mobilização da AMFNB, eram considerados "perigosos" e, assim, deveriam ser rapidamente retirados do convívio de bordo. Procedimento este que, conforme expressamos anteriormente, era parte integrante da "operação limpeza" levada a cabo nos quadros da força naval. E que, como aponta o trecho da narrativa a seguir, não foi exclusividade do cruzador Tamandaré:

\begin{abstract}
Aí passou mais uma semana nos mandaram lá pro (sic.) quartel ${ }^{43}$, aliás, mandaram a turma pro quartel. E eu eles não tinham me chamado pro quartel, eu agarrei tinha pedido [...] tinha um desembarque pra (sic.) [...] parece que era São Pedro da Aldeia ${ }^{44}$, parece que era São Pedro.
\end{abstract}

40 BNM 639, p. 99-102 - Elementos de informação, anexo ao ofício n ${ }^{\circ} 447$ de 24 de abril de 1964 do cruzador Tamandaré.

41 Unidade da Marinha criada através do Decreto Imperial $\mathrm{n}^{\circ} 49$ de 22 de outubro de 1836, foi também denominada ao longo dos anos como "Quartel das Companhias Fixas de Marinheiros", "Quartel das Companhias de Marinheiros Imperiais" e "Quartel das Companhias de Marinheiros Nacionais". Tendo funcionado em diversas unidades navais, como: Ilha de Villegagnon, Ilha das Cobras, encouraçado Floriano e cruzador Barroso, por exemplo. Desde 1958 funciona em estabelecimento próprio, situado no bairro da Penha, atual cidade do Rio de Janeiro-RJ.

42 Termo empregado na Marinha para fazer referência a um local de espera. Em alusão às boias nas quais, em alguns casos, os navios ficam aguardando oportunidade de atracação no porto, daí vem a expressão marinheira "aguardar na boia". 43 Aqui o entrevistado se refere ao Quartel de Marinheiros. 44 Cidade litorânea do estado do Rio de Janeiro, situada na região dos lagos, onde está fixada a Base Aeronaval da Marinha.
E eu pedi pra desembarcar pra lá, só que eu tinha que passar pelo quartel pra ir pra lá. Aí cheguei ao quartel, a turma tava (sic.) tudo lá, e começaram a dizer que [...] que a turma chamava do pessoal do rabo né, o pessoal do rabo era o pessoal que tava pra ir pra rua por causa da política, entende? "Ó lá na turma do rabo, quando faz a chamada, tão te chamando, chamam teu nome também." Eu digo: "ah mas não me desembarcaram?” E eles diziam: "Não sei vê o que tu vai fazer aí, tão (sic.) te chamando lá também.” E onde eu tava não fazia nem chamada também. Eu digo: "Sabe de uma coisa, vou lá falar com eles." Falei com o oficial lá, eu disse: "ah tão me chamando lá na turma do rabo, lá na turma da justiça.” Aí o cara foi ver, realmente o meu nome tava na relação. Aí me passaram [...] já não fui mais pra onde eu ia, aí fui pra turma do rabo, que ia pra rua. Aí daí me mandaram pra rua.

No relato acima, onde o "Entrevistado A" narra a maneira como foi expulso da Marinha, é possível perceber que, a exemplo de Paulo Costa, ele também foi "desembarcado" de seu navio - cruzador Barroso - para aguardar o desfecho das apurações acerca de sua participação nos desdobramentos da mobilização da AMFNB.

Neste sentido, quando o entrevistado refereseà “turma do rabo ${ }^{45 ",}$, percebemos que ele faz alusão aqueles militares que, por seus posicionamentos e concepções políticas ou eventual envolvimento com a mobilização "fuzinauta", haviam sido "movimentados" de suas unidades e concentrados no Quartel de Marinheiros. Onde aguardaram os desdobramentos da "operação limpeza" que se realizava na Marinha.

Acerca de sua relação com a AMFNB, o "Entrevistado A" afirma o seguinte em sua narrativa:

Não me lembro se quando eu cheguei no (sic.)
Rio [...] eu acho que já tinha essa associação,
não me lembro direito. [...] eu algumas vezes
até cooperei. Algumas vezes porque eu andava
sempre na pior, aí cooperei. Mas eu nunca fui,
eu nunca entrei na associação. [...] E aí, bom
eu nunca participei de reunião nenhuma na
associação. [...] Inclusive essa reunião que foi a
primeira e a última que eu fui, eu até não ia ir
(sic.) a essa reunião. 45 Segundo o "Entrevistado A" a expressão "turma do rabo de foguete" fazia referência aqueles militares que estariam respondendo IPM's por envolvimento, em alguma medida, com a mobilização da AMFNB. Expressão consagrada no contexto da ditadura civil-militar brasileira quando cantada na música de Aldir Blanc e João Bosco O Bêbado e o Equilibrista. 
Ao ser preso pela participação na assembleia do dia 25 de março, e, mais especificamente, por ter permanecido no Sindicato dos Metalúrgicos da Guanabara após a decretação de prontidão rigorosa na Marinha, o "Entrevistado A" teria afirmado em seu depoimento que:

[...] entrou para a associação logo após a sua fundação [...] e que compareceu a outras reuniões da associação, recordando-se de uma no sindicato dos securitários [...] e ainda, que não se apresentou a ser determinada prontidão porquanto já estava aquartelado e solidário com os colegas.

Desta maneira, verificam-se algumas contradições entre os trechos acima, isto é, discursos distintos em fontes diferentes acerca de uma realidade vivenciada pelo entrevistado. Considerando os constantes silenciamentos e negativas em sua narrativa, bem como, o passado traumático vivenciado pelo ex-militar a partir do instante em que foi expulso das fileiras navais e regressou a sua cidade natal, conforme veremos adiante. Acreditamos que, especialmente para este entrevistado, aquele é ainda um "passado muito presente" em sua vida. Isto é, o silenciar ou esquecer são opções de memória, assim como o recordar, que é "uma re-presentificação (sic.) [Grifo do autor] doadora de futuros a um passado" (CATROGA, 2001, p.25) em constante reconstrução.

De modo que, não cabe aqui buscarmos onde a "verdade" estaria estabelecida, visto que, tanto o depoimento colhido à época - como parte do IPM instaurado pela portaria $n^{\circ} 0540$ - quanto a entrevista realizada no contexto da presente pesquisa, constituem-se enquanto fontes de memória. E, portanto, "fruto de rememoração 'quente' [...] que não se limita a evocar o passado; ao contrário, ela deseja transformá-lo, em ordem a ultimar-se que o tempo deixa sempre inacabado". (CATROGA, 2001, p.21) Mas o fato é que, destas narrativas podemos apreender importantes aspectos acerca do entrevistado e sua vivência à época, entre os quais destacamos o fato de ele ter sido preso no contexto da realização da assembleia no "Palácio de Aço". Identificado, inclusive, em fotos da imprensa à época, nas quais figurava ao lado do almirante Cândido Aragão durante a referida assembleia. A quem afirmava ter conhecido "nos dias da revolução, mas nunca chegou a falar com ele."

Frente a esse contexto, o "Entrevistado A", no entendimento da alta administração naval, era um militar "perigoso" e que deveria ser expurgado dos quadros de subalternos da Marinha. E, sendo natural de Pelotas-RS, suas relações na cidade de Rio Grande-RS não poderiam deixar de ser consideradas no contexto repressivo da "operação limpeza" que se desenrolava também na urbe riograndina. Neste cenário, a 9 de outubro de 1964, no mesmo ato ${ }^{46}$ que expulsou outros três membros da associação "fuzinauta", naturais de Rio Grande-RS e cercanias - Evaldo Luiz Ferreira de Souza, Fernando Antonio Pinho Marchese, e Miguel Arcanjo Vera Cruz - o "Entrevistado A" foi sumariamente excluído da Marinha. Tendo ainda sido denunciado à justiça militar, após a conclusão do IPM, em 5 de junho de $1964^{47}$, por ter "cometido o delito previsto no

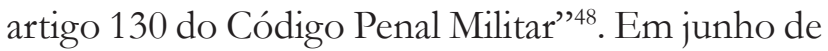
1966 o "Entrevistado A" teve mandado de prisão expedido em seu nome, sendo condenado a cinco anos e dois meses de reclusão pela prática do crime de que foi denunciado em 1964.

Nesse cenário, dos três marinheiros expulsos da Marinha através do mesmo ato que expulsou o "Entrevistado A", os dois primeiros eram amigos pessoais de Paulo Costa. Sendo que, segundo ele, Evaldo Luiz seria natural de Rio Grande-RS cuja família residia no Bairro Getúlio Vargas, já

46 Arquivo da união dos militares não anistiados (UMNA) Conforme Ato n⿳365 de 30 de setembro de 1964, publicado no Boletim do Ministério da Marinha no 41, de 9 de outubro de 1964, e fundamentado no Art. 103 alínea "f" do Decreto $\mathrm{n}^{\mathrm{o}} 44.061$ de 23 de julho de 1958.

47 BNM 149 - p.2686-2721.

48 BNM $149-$ p.2689. 
Marchese seria natural de Pedro Osório-RS, cidade a aproximadamente 130 quilômetros da urbe riograndina.

Evaldo Luiz Ferreira de Souza e Fernando Marchese ingressaram na Marinha no ano de 1961 através da EAMSC, juntamente com Paulo Costa, onde, segundo este, teriam se destacado durante o curso, tendo sido Evaldo Luiz o segundo colocado de sua turma naquele ano. Ao final do curso na EAMSC, já em 1962, seguiram para o Rio de JaneiroRJ, onde foi designado para servir no cruzador Barroso, mesmo navio onde servia o "Entrevistado A", enquanto que Fernando Marchese passou a integrar a Força de Contratorpedeiros.

No contexto da "operação limpeza" nos quadros de subalternos da Marinha, ambos também foram submetidos ao IPM instaurado pela portaria $n^{\circ} 0540$, cujo encarregado era o capitão de fragata Paulo Bonoso Duarte Pinto, sendo presos para "averiguações" em 14 e 24 de abril de $1964^{49}$, respectivamente, por solicitação direta deste oficial ao Ministro da Marinha. Neste cenário, em depoimento prestado no contexto do referido IPM, ao qual foi submetido por participar da assembleia do dia 25 de março no "Palácio de Aço", Evaldo Luiz afirmou que:

[...] é sócio da Associação de Marinheiros da categoria de contribuinte desde março de 1963; que entrou para a Associação (sic.) com a finalidade de usufruir das facilidades fornecidas no que diz respeito a estudo; que desde que veio da Escola de Aprendizes procurou levar (sic.) adiante seus estudos, para isso ingressando no Humaitá Atlético Club, que permaneceu no curso Humaitá somente três meses, pois, recebendo somente Cr\$ 2.600,00 tinha que pagar a mensalidade de $\mathrm{Cr} \$ 1.000,00$ no referido curso, o que não conseguiu aguentar; que a seguir transferiuse para o curso Central [...] porém como ainda pagava Cr\$ $1.000,00$ por mês teve que abandonar, procurando então o Colégio Benjamin Constant que era da Associação de Marinheiros e Fuzileiros onde tinha que pagar somente sua mensalidade de sócio de Cr\$ $300,00 .^{50}$

49 BNM $149-$ p.2683-2684.

50 BNM 149 - p.686.
Ao observarmos o trecho do depoimento acima, bem como, a afirmação de Paulo Costa quanto ao desempenho de Evaldo Luiz em sua turma durante o curso na EAMSC, percebemos que, através dos estudos, ele buscava resistir à realidade que se impunha a marinheiros e fuzileiros na força naval. Contrariando assim o paradigma comum aqueles militares, o qual, como já mencionamos, contribuía para a manutenção de uma relação hierárquica com a oficialidade que, para além dos estatutos militares, se fundamentava em uma disciplina social. Ainda em seu depoimento, Evaldo Luiz relata o seguinte:

[...] que compareceu a outras reuniões da Associação de Marinheiros (sic.), sendo que duas no Ministério da Educação para tratar de assuntos referentes ao Estatuto da associação, que chegou ao Sindicato (sic.) no dia 25 cerca das 20:15 horas, não tendo sido iniciada a sessão [...] que a seguir falaram oradores civis e militares que falaram normalmente sobre as reivindicações da classe, a saber: vencimentos, facilidades para o estudo, tratamento mais condigno para com os marinheiros por parte dos oficiais em relação as praças membros da Associação (sic.), estabilidade para os marinheiros, melhoria de acesso na carreira das praças, distribuição dos subalternos em estabelecimentos navais e navios dos estados de origem [...] que os portões do Sindicato dos Metalúrgicos não foram fechados à ninguém que quisesse entrar ou sair ${ }^{51}$ (Grifo nosso).

O trecho acima denota o seu engajamento junto à mobilização dos marinheiros, na medida em que era membro atuante da associação "fuzinauta" e conhecedor de suas reivindicações, em especial aquelas afetas a questões ligadas à carreira e ao acesso aos estudos. Deste modo, Evaldo Luiz Ferreira de Souza foi considerado, durante as apurações decorrentes do IPM, como uma das lideranças da AMFNB, e, portanto, um dos "cabeças" 52 da mobilização ocorrida no Sindicato dos Metalúrgicos da Guanabara-RJ. Tendo sido, também, denunciado à justiça militar por ter "cometido o delito previsto no artigo 130 do Código Penal Militar, com o aumento de pena 51 BNM $149-$ p.686-687. 52 BNM $149-$ p.2652. 
atribuído aos cabeças" ${ }^{53}$. E, ainda em junho de 1964, durante o transcurso do processo n 8167 da $1^{\text {a }}$ Auditoria da Marinha, Evaldo Luiz teve sua prisão preventiva decretada ${ }^{54}$. Tendo permanecido preso durante aproximadamente nove meses, até ser expulso da Marinha em outubro de 1964. Segundo Paulo Costa, o ex-marinheiro teria permanecido trabalhando no Rio de Janeiro-RJ, no estaleiro Ishikawajima, até meados de 1966, quando teve mandado de prisão ${ }^{55}$ expedido em seu nome. Até esse momento, Evaldo Luiz manteve contatos com integrantes de movimentos da esquerda armada, como veremos mais adiante.

Do mesmo modo, Fernando Antônio Marchese, ao final do IPM levado a cabo pelo capitão de fragata Paulo Bonoso, também foi denunciado à justiça militar como um dos "cabeças" durante a assembleia "fuzinauta" iniciada no dia 25 de março. O militar, que à época servia no contratorpedeiro Paraíba, ao ser interrogado durante o referido IPM afirmou o seguinte:

[...] que é membro da associação desde janeiro de 1964 [...] que chegou ao Sindicato dos Metalúrgicos às 19:20 horas, que dos pronunciamentos feitos pela diretoria concorda com as reivindicações da classe que considera justas e líquidas: vencimentos muito baixo (sic.) de cabo para baixo e alimentação deficiente, quanto a este aspecto declara considerar péssima e pouca a do CT "Apa" 56 [...] que considera um absurdo um marinheiro não poder casar-se [...] que durante a reunião concordou com a diretoria com as providências tomadas enquanto a assembleia permanente ${ }^{57}$ (Grifo nosso).

Em seu depoimento, assim como Evaldo Luiz Ferreira de Souza, Fernando Marchese se mostrou articulado e conhecedor das demandas dos marinheiros, além de evidenciar uma significativa noção de pertencimento ao que considera a "classe" dos marinheiros. Deixando evidente

53 BNM $149-$ p.2687.

54 BNM $149-$ p.2730-2732.

55 BNM 149 - p. 5113.

56 Contratorpedeiro (CT) Apa.

57 BNM 149 - p.1984. também o seu descontentamento quanto a questões que fundamentavam as demandas daqueles militares. Especialmente aquelas afetas à carreira e às condições de vida e trabalho às quais estavam submetidos na Marinha cabos, soldados e marinheiros. Desta maneira, consideramos que Fernando Antônio Marchese entendia a AMFNB como um meio de apresentar essas demandas e buscar, junto à alta administração naval, o atendimento das mesmas. Desse modo, por sua participação na assembleia do dia 25 de março, bem como, por seus posicionamentos quanto às "reivindicações da classe" e atuação na AMFNB, Fernando Marchese foi considerado, também, um dos "cabeças" da mobilização. E, juntamente com Evaldo, teve sua prisão preventiva ${ }^{58}$ decretada pela $1^{\mathrm{a}}$ Auditoria da Marinha em junho de 1964. Em outubro daquele ano, Fernando Antônio Marchese foi também expulso da Marinha através do ato no 365 , e ainda, assim como Evaldo Luiz, em julho de 1966 foi expedido mandado de prisão ${ }^{59} \mathrm{em}$ seu nome por ter sido condenado ${ }^{60}$ a cinco anos de prisão.

Nesse contexto, destacamos ainda a expulsão de Miguel Arcanjo Vera Cruz, "expurgado" dos quadros da força naval através do mesmo ato que excluiu o "Entrevistado A" e Evaldo Luiz, com os quais servia à época no cruzador Barroso, sendo transferido para o Quartel de Marinheiros logo após o golpe. Em depoimento Miguel Arcanjo afirmou que:

[...] entrou para a Associação dos Marinheiros e Fuzileiros Navais do Brasil no fim do ano de 1962, com o propósito de ter onde se divertir e estudar, que em outubro de 1963 compareceu a uma reunião na associação, que $\mathrm{o}$ fez responder a um IPM, que em nenhuma outra reunião compareceu, que foi ao Sindicato dos Metalúrgicos pensando encontrar lá uma festa [...] chegando ao sindicato cerca das 19:00 horas, que lá permaneceu ouvindo os discursos nos quais era pregada a necessidade de aumento nos vencimentos, de melhoria das condição a bordo, etc. [...] que permaneceu no sindicato por se sentir solidário com as reivindicações lá apresentadas. ${ }^{61}$

\footnotetext{
58 BNM $149-$ p. $2730-2732$.

59 BNM 149 - p.5113.

60 BNM 149 - p. 5105.

61 BNM $149-$ p.2236.
} 
No trecho acima, o ex-marinheiro se refere à única reunião da qual teria participado antes da assembleia no "Palácio de Aço", na verdade, está se referindo à assembleia geral extraordinária realizada em $1^{\circ}$ de outubro de 1963. Nesta reunião foram deliberadas providências a serem tomadas em face das prisões administrativas de José Anselmo dos Santos e Avelino Capitani, presidente e vice-presidente da associação "fuzinauta", respectivamente. Miguel Arcanjo foi submetido ao IPM instaurado para apurar os acontecimentos na referida assembleia e, ao final do mesmo, arrolado como testemunha ${ }^{62}$ na denúncia oferecida à justiça militar pela prática do crime previsto no artigo 144 do CPM por parte de alguns integrantes da referida assembleia. Dessa forma, ao participar dos acontecimentos ocorridos no Sindicato dos Metalúrgicos da Guanabara-RJ, Miguel Arcanjo passou também a ter apuradas, pelo devido IPM, suas responsabilidades durante aquele episódio. De modo que, ainda em seu depoimento acerca dos acontecimentos na assembleia do dia 25 de março ele relatou:

[...] que no dia 27 foi transportado para o Batalhão de Guardas de onde foi libertado cerca das 18:30 horas, tendo se dirigido diretamente para o quarto de um irmão de seu colega [...] que tinha estado no Sindicato dos Metalúrgicos. ${ }^{63}$

O colega ao qual Miguel Arcanjo Vera Cruz se refere é o "Entrevistado A", que residia no morro do Santo Cristo ${ }^{64} \mathrm{com}$ seu irmão, também marinheiro. A relação entre estes militares que, juntamente com Evaldo Luiz, serviam juntos no mesmo navio e eram naturais da zona sul gaúcha, mais precisamente de Rio Grande-RS e adjacências. E ainda, a atuação dos mesmos na associação "fuzinauta", bem como, sua participação na assembleia ocorrida entre os dias 25 e 27 de março no "Palácio de Aço" na Guanabara-RJ, foram 62 BNM $149-$ p.2601-2602.

63 BNM $149-$ p.2237.

64 Localidade situada nas cercanias da zona portuária da cidade do Rio de Janeiro-RJ suficientes para que a alta administração naval, no contexto da "operação limpeza", os considerasse elementos subversivos e, portanto, "prejudiciais à ordem pública e à disciplina militar." Neste sentido, Miguel Arcanjo "seguiu os passos” de seus companheiros aqui mencionados, sendo também denunciado à justiça militar pelo crime previsto no artigo 130 do CPM. E, após ser expulso da força naval, foi condenado ${ }^{65}$ pela $1^{a}$ Auditoria da Marinha a cinco anos e dois meses de prisão. Sendo então, no dia $1^{\circ}$ de julho de 1966 , expedido mandado de prisão ${ }^{66} \mathrm{em}$ seu nome.

No contexto destas "apurações" e punições que se sucederam sobre subalternos da Marinha, destacados membros e lideranças da associação "fuzinauta" foram "expurgados" dos quadros da força naval. Entre estes estavam militares que ainda que lotados em navios e quartéis sediados no Rio de Janeiro-RJ - por razões familiares, afetivas e/ou profissionais, mantinham relações em cidades da zona sul gaúcha, principalmente em Rio Grande-RS. Relações estas que apontam para uma atuação da AMFNB na urbe riograndina, em um contexto de significativa expansão daquela associação junto aos quadros de subalternos da Marinha em todo país, associado ao cenário político social tensionado da época. No qual, desde a crise da sucessão presidencial em 1961, Rio Grande-RS já desempenhava relevante papel, não somente no cenário gaúcho, mas também nacional.

Neste enredo, Guillem Rodrigues, Paulo Costa, "Entrevistado A", Evaldo Luiz, Fernando Marquese, Miguel Arcanjo, Ubirajara Teixeira e Mabel Tomaz são apenas alguns dos muitos militares que, oriundos de Rio Grande-RS e cercanias, integraram a AMFNB. E que, por esta razão, sofreram severas consequências tanto na esfera administrativa quanto - na maioria dos casos analisados - no âmbito penal.

65 BNM $149-$ p. 5106.

66 BNM 149 - p.5117. 
Durante o processo de expurgo, enquanto parte da "operação limpeza" levada a cabo nos quadros da Marinha, foram punidos previamente centenas de militares, em sua maioria absoluta praças nas graduações iniciais da carreira naval. Os quais não tiveram chance de se defender antes de serem expulsos ou demitidos compulsoriamente da força naval. Muitos dos quais também não tiveram chance de defesa nos processos penais a que foram submetidos, pois, expulsos das fileiras da Marinha, já se consideravam punidos, e, assim, voltaram às suas cidades de origem a fim de reconstruir suas vidas.

Neste contexto, conseguimos perceber o esforço da alta administração naval em excluir de suas fileiras aqueles militares que, de algum modo, estiveram envolvidos com a mobilização da AMFNB. Mesmo que, em alguns casos, não fosse possível imputar-lhes responsabilidades objetivas em determinados acontecimentos. No caso de Rio Grande-RS, este esforço se deu em dois sentidos, isto é, na "limpeza" da cidade e no "expurgo" daqueles militares que, comprovada ou potencialmente, atuavam na urbe riograndina enquanto membros ou representantes da AMFNB. Podendo assim, em um cenário político tensionado e marcado por mobilizações sociais, estabelecer contatos com subalternos da força naval, além de lideranças políticas e sindicais da cidade.

Deste modo, capitaneada pela Marinha, a "operação limpeza" continuou atuante na urbe riograndina. Especialmente no que concerne à continuada vigilância e à perseguição aqueles que outrora foram membros da AMFNB. Homens que, depois de terem sido jogados "pela borda", ou seja, excluídos da Marinha, voltaram à zona sul do estado gaúcho buscando recomeçar suas vidas depois da "tempestade".

\section{Depois da "tempestade"}

Após enfrentarem uma intensa repressão no Rio de Janeiro-RJ, marcada por uma condenação prévia que encerrou abruptamente as carreiras de centenas de praças da Marinha, ainda no ano de 1964, muitos daqueles marinheiros e fuzileiros navais buscaram outros caminhos para reconstruírem suas vidas. Caminhos estes que, em algum momento, sobretudo por questões familiares e afetivas, os conduziram de volta às suas cidades de origem. No caso das cidades da zona sul do estado gaúcho, especialmente Rio Grande-RS, esta volta a um "porto seguro" por parte dos membros da AMFNB expulsos da força naval no contexto inicial da "operação limpeza", se mostrou tormentosa para aqueles ex-militares. Nesse sentido, analisaremos, por fim, a vigilância constante e a repressão que se abateram sobre os mesmos a partir de Rio Grande-RS. Em especial, no quadro dos desdobramentos das ações penais impetradas contra aqueles militares ainda no ano de 1964, as quais resultaram em diversas condenações durante os anos que se seguiram.

Assim, após viver dias de intensa repressão e terror com a presença ostensiva de um "navio prisão" fundeado ao largo de seu porto durante praticamente todo mês de abril do ano de 1964. A cidade de Rio Grande-RS passou a conviver com a presença e atuação ostensivas das forças de repressão. Neste cenário é que muitos exmarinheiros, que anos antes haviam ingressado na força naval através da urbe riograndina, retornaram às suas cidades de origem em busca de um recomeço em suas vidas ou apenas de refúgio. Mas naquele contexto tensionado dos anos que se seguiram ao golpe civil-militar, os ex-associados ou apoiadores 
da AMFNB que regressavamà Rio Grande-RS e demais cidades situadas na zona de influência da autoridade naval sediada na urbe riograndina, continuaram a ser monitorados e perseguidos pelas autoridades navais.

Dessa forma, consideramos que a repressão contra aqueles militares, iniciada no momento em que foram sumariamente excluídos da Marinha pelo fato de "terem se tornado prejudiciais à ordem pública e à disciplina militar", teve continuidade em Rio Grande-RS. Pois, o esforço dos órgãos de repressão - capitaneados pela Marinha - para "limpar" a outrora "cidade vermelha" não poderia ser comprometido por uma possível atuação de exmilitares membros da associação "fuzinauta". Deste modo, não obstante seu reduzido contingente local, a Marinha exercia significativo controle social na urbe riograndina, ao ponto de o capitão dos portos à época do golpe, Mario Rodrigues da Costa, ser conhecido pelo apelido de "reizinho". Dessarte, destacamos o aspecto da vigilância constante exercida em uma cidade assombrada pelo temor da volta do "navio branco", Canopus". O que contribuía para uma rigorosa observância das ações e relações pessoais daqueles que eram considerados suspeitos de subversão. Entre os quais destacamos algumas lideranças e integrantes da mobilização dos marinheiros que, de algum modo, regressaram à Rio Grande-RS e cercanias.

Entre estes ex-militares estavam alguns que, mesmo tendo destacada atuação na AMFNB inclusive na urbe riograndina-enquanto integraram os quadros de subalternos da Marinha, não foram condenados na esfera penal. Foi o caso de Mabel Tomaz Gonçalves e Paulo Costa, que após serem expulsos da força naval em 1964 regressaram à urbe riograndina e a fim de "recomeçarem" suas vidas.

67 Navio hidrográfico, cujo indicativo naval era H-22, ostentava cor branca, característica dos navios dedicados a estudos e pesquisas nas águas brasileiras, subordinados à Diretoria de Hidrografia e Navegação (DHN). Foi empregado como navio prisão em Rio Grande-RS durante o mês de abril de 1964, onde ficaram detidas diversas lideranças da cidade, entre civis e militares.
Neste enredo, por seus posicionamentos políticos e engajamento no movimento "fuzinauta" enquanto esteve na Marinha, destacamos Paulo Costa. Que permaneceu durante mais alguns meses no Rio de Janeiro-RJ e, em fevereiro de 1965 regressou à Rio Grande-RS, onde, já no ano seguinte, veio a constituir família.

Acerca da impressão que teve quando regressou à cidade em 1965, Paulo Costa diz que naquele ano "não podia ter três na esquina que era complô." Referindo-se ao clima de vigilância constante e de repressão vivenciado na urbe riograndina. Mas, ainda assim, por não ter sido condenado durante o curso das ações penais na justiça militar, teve relativa tranquilidade para buscar, em sua cidade natal, uma nova vida no meio civil. Porém, o então passado recente como membro da AMFNB com destacada atuação, inclusive em Rio Grande-RS, literalmente bateu à sua porta. Seu amigo Evaldo Luiz, dos tempos da EAMSC e da associação "fuzinauta", procurou-lhe em sua residência. Em sua narrativa Paulo Costa relata o seguinte diálogo que teve com seu amigo:

Eu sabia que ele tinha saído e que tava no Rio também. Em abril de 66 a minha esposa tava (sic.) grávida de meu filho mais velho, eu morava no centro da cidade de Rio Grande, Zalony 208. Bate (sic.) na porta eu vou (sic.) atender, um negão com camisa cor de rosa, uma tora de forte, ele era forte, o bicho jogava basquete, praticava halterofilismo, um cara inteligentíssimo, segundo colocado da nossa turma. Eu disse: "Pois Evaldo o que tais fazendo aqui?" Mandei ele entrar. Ele chega (sic.) e disse: "Sssss." (como fazendo sinal de silêncio) Eu disse: "Mas aí Evaldo o que tu veio fazer aqui?" Disse ele pra (sic.) mim: "Eu vim pra te levar." [...] "Pra me levar onde (sic.) rapaz." Ele disse: "To (sic.) com o dinheiro, to com as passagens, a hora que eu quiser já tá na mão. Vamos pra Cuba?" Disse pra ele: "Mas que isso velho, não faz isso." E eu era, sou sócio do Clube de Regatas Rio Grande. Aí eu disse: "Não, vamos lá no clube, tu vai jogar um basquete e vamos tomar um guaraná." E levei ele lá no clube, aí o negão bateu umas bolinhas lá, nós jogamos de dupla e tal, e fomos até o barzinho tomar uísque. Aí tentei e ele disse: "Mas Paulinho, não tem como eu recuar agora tchê. Eu to até o pescoço nisso aí, entendeu. Eu vou. [...] Eu vim aqui especialmente lhe ver, pra te levar junto." Eu disse: "A minha esposa tá grávida cara, eu não vou." 
O diálogo narrado acima denota uma relação muito próxima entre Evaldo Luiz e Paulo Costa, mas também reforça a ideia de que este último seria, de fato, um destacado membro da AMFNB. Suscitando assim, questionamentos sobre um eventual envolvimento seu com movimentos da esquerda que viriam a se engajar na luta armada contra a ditadura. E ainda, sobre uma eventual mobilização daqueles grupos a partir de Rio GrandeRS. Questionamentos que consideramos relevantes e que, necessariamente, devem ser aprofundados oportunamente. Uma vez que, em um contexto de disputa de memórias, esta é "instância cimentadora de identidades, a sua expressão coletiva também atua como instrumento e objeto de poder(es) (sic.) mediante a seleção do que se recorda e do que, consciente ou inconscientemente, se silencia" (CATROGA, 2009, p. 78)

Destarte, o fato de Evaldo Luiz Ferreira de Souza ter retornado à cidade onde residia antes de ingressar na Marinha, segundo Paulo Costa, para convidá-lo a integrar a luta armada, indica o grau de engajamento político deste exmarinheiro, bem como, sua posição de liderança junto ao movimento "fuzinauta". E ainda, ao relatar que tinha conhecimento de que Evaldo Luiz não estava mais no Rio de Janeiro-RJ no ano de 1966, quando foi condenado à prisão pela justiça militar, Paulo Costa deixa claro que mantinha contatos naquela cidade. De modo que, mesmo em Rio Grande-RS, continuava acompanhando os desdobramentos da repressão sobre seus antigos companheiros de associação.

Paulo Costa afirma ainda que durante muitos anos, no transcurso da ditadura, foi continuamente acompanhado e vigiado em Rio Grande-RS. No contexto de uma vigilância constante exercida pela Marinha com o apoio de parcela significativa da sociedade riograndina, haja vista o reduzido contingente da força naval naquela cidade. Neste sentido, em seu relato ele diz o seguinte:
[...] o Pedroso [...] era muito amigo do meu pai, entendesse. Em 1985, em outubro de 1985, eu to (sic.) na porta do meu escritório e ele chega: "Oi Saraivinha." Me chamava de Saraivinha, o meu pai era Valter Saraiva, eu não tenho Saraiva no nome, mas todo mundo me chamava de Saraivinha. Começou a estourar aquela inflação voltar aquele negócio todo, os militares tavam (sic.) largando né (sic.), ia ter a eleição em 86. [...] Ele me disse: "Porra e tu acredita, tu fosse monitorado todo esse tempo." Ele fazia parte de uma comissão, que existia comissão dentro de Rio Grande, entendesse, seguindo os passos daqueles que eles suspeitavam que podiam fazer alguma coisa contra o regime. Eles me monitoraram durante todos esses anos cara, entendesse.

O acompanhamento exercido sobre antigos e potenciais "subversivos" na urbe riograndina, contando inclusive, segundo Paulo Costa, com uma comissão para este fim. Fundamentavase em um colaboracionismo entreguista que imperou na maioria das localidades brasileiras onde atuavam as forças de repressão da ditadura. Este colaboracionismo com a repressão, no sentido de entregar aqueles considerados, em alguma medida, subversivos ou suspeitos de subversão, se apoiava também no temor de muitos em se tornarem vítimas da "máquina" repressora do Estado. Deste modo, em Rio Grande-RS, a "sombra” do Canopus enquanto instrumento da ditadura empregado contra seus opositores, bem como, a simples possibilidade de seu retorno à urbe riograndina com esta finalidade, em muito colaborou para incrementar o clima de desconfiança e a vigilância constante entre os cidadãos daquela cidade.

No que concerne a Evaldo Luiz Ferreira de Souza, de fato ele ingressou na luta armada, seguindo para o exílio ainda no ano de 1966, logo após sua condenação pela justiça militar. Segundo o relatório da Comissão Nacional da Verdade (CNV):

Evaldo passou cinco anos em Cuba, onde recebeu treinamento de guerrilha, já engajado aos quadros da VPR. Quando regressou ao Brasil, instalou-se em Recife no contexto de reorganização da VPR no Nordeste. Evaldo Luiz Ferreira de Souza [...] foi morto junto com outros cinco integrantes da VPR, entre os dias 8 e 9 de janeiro de 1973, no episódio 
conhecido como massacre da Chácara São Bento, em Pernambuco. ${ }^{68}$

De modo semelhante a Evaldo Luiz, outros ex-militares integrantes da AMFNB condenados pela justiça militar - naturais de Rio Grande-RS ou cujas famílias haviam se fixado na cidade - também seguiram para o exílio ou buscaram refúgio no interior do estado gaúcho. Como o caso de Guillem Rodrigues que seguiu de Rio Grande-RS para o exílio iniciado no Uruguai. Já no início da década de 1970 Guillem Rodrigues chegou à Suécia, onde se estabeleceu e, durante todo o período em que vigorou a ditadura no Brasil, prestou apoio a refugiados e exilados políticos brasileiros naquele país. Regressando ao Brasil somente no ano de 2009. Entre aqueles que, mesmo condenados permaneceram em Rio Grande-RS e outras cidades da zona sul gaúcha, destacamos Ubirajara Goulart Teixeira e "Entrevistado A". Ambos foram presos durante os desdobramentos da "operação limpeza" no Rio Grande do Sul, ao que tudo indica, desconheciam suas condenações na justiça militar, haja vista que procuravam seguir suas vidas dentro da normalidade.

Neste sentido, o "Entrevistado A", que havia voltado para Pelotas-RS ainda no ano de 1964, foi preso $^{69}$ naquela cidade em fevereiro de 1969, quando já estava empregado e havia constituído família. Em seu relato "Entrevistado A" narra como se deu sua prisão:

Aí depois, não sei quantos anos depois, eu estava trabalhando no Fonseca Júnior, na oficina. Aí quando eu vi chegou a caminhonete da polícia civil me prendendo, que eu tinha sido condenado a 5 anos e 3 meses, me condenaram a revelia. Assim como condenaram outros a revelia também. [...] Como subversivo. E na época o inspetor que foi me prender, que me prendeu ali no Fonseca. Quando eles iam me levando pra (sic.) delegacia, foram dois inspetor (sic.), eles disseram: “Ó, o negócio é

68 Comissão Nacional da Verdade - Relatório. Vol.3, dez.2014, 248-Evaldo Luiz Ferreira de Souza.

69 Arquivo Público do Estado do Rio Grande do Sul (APERS) - Processo no 1770-1200/02-7 - Declaração da empresa Fonseca Júnior acerca da prisão de seu funcionário. o seguinte, tu vai ser preso incomunicável." Mas cheguei na (sic.) cadeia não tinha como ficar incomunicável, porque tava cheia a cadeia, entendeu? Aí me botaram numa cela lá com outros caras lá. [...] Pô (sic.) e quando me prenderam, eu tava (sic.) trabalhando aí, [...] Não tinha um ano ainda de casado. Eu casei em maio e em fevereiro, dia 19 de fevereiro me prenderam. A mulher barriguda, a mulher já tava bem barriguda e aí, aí me prenderam.

Tendo se passado quase cinco anos dos acontecimentos pelos quais foi condenado em 1966, em sua narrativa podemos perceber que na ocasião em que foi preso o "Entrevistado A" já estava restabelecido em sua cidade natal. Recolhido à Cadeia Civil de Pelotas-RS ${ }^{70}$, o ex-militar cumpriu pouco mais de dois anos em regime fechado por ter sido considerado incurso, em julgamento à revelia, no crime de motim durante os acontecimentos no Sindicato dos Metalúrgicos da Guanabara-RJ, em março de 1964. Devido a seu pai ser membro da Brigada Militar à época, possivelmente, o exmarinheiro não teria sido encaminhado para o Rio de Janeiro-RJ, a fim de ser interrogado pelas autoridades navais e pela justiça militar naquela cidade. Tendo permanecido em Pelotas-RS durante a execução de sua pena.

Já o ex-soldado fuzileiro naval Ubirajara Goulart Teixeira, também julgado à revelia e condenado, juntamente com o "Entrevistado A", como incurso no mesmo crime pelo qual foi condenado o referido ex-marinheiro. Após ser preso $^{71}$ por agentes do Departamento de Ordem Política e Social (DOPS), no dia 14 de setembro de 1971 em sua casa na cidade de Alegrete-RS, foi encaminhado ainda no mesmo dia para Porto Alegre-RS. Onde permaneceu à disposição das autoridades policiais até o dia 8 de outubro de 1971, quando foi transferido para o Rio de JaneiroRJ. Ao chegar na urbe fluminense, Ubirajara Teixeira permaneceu preso, em princípio, na área do Comando do $1^{\circ}$ Distrito Naval, onde foi

70 APERS - Processo no $1770-1200 / 02-7$ - p.13.

71 APERS - Processo no 2421-1200/02-3 - p. 4-6. 
interrogado pelas autoridades navais e, também, pela Auditoria da Marinha. A partir deste momento, passou por vários estabelecimentos penais no estado do Rio de Janeiro, entre os quais destacamos os Presídios Cândido Mendes e o da Ilha Grande, onde se concentravam os presos políticos.

Desde o instante de sua prisão, em 1971, Ubirajara Goulart Teixeira sofreu significativos maus tratos e severas restrições por parte de seus repressores. Em requerimento apresentado à Comissão Especial de Indenização a Ex-Presos Políticos do Rio Grande do Sul, o ex-militar relatou que, enquanto era encaminhado para a capital gaúcha, horas após sua prisão:

Entre Rosário e São Gabriel [...] estacionaram a Kombi e fui perguntado se queria urinar, disse que sim e desci para urinar. Fui interrompido por uma saraivada de tiros de pistola e submetralhadora. Com os tiros parei de urinar com uma dor aguda na bexiga e nervoso com as atividades dos policiais não consegui mais urinar, por mais esforço que fizesse. ${ }^{72}$

Ubirajara Teixeira afirmou ainda, neste mesmo requerimento, que foi submetido a longos períodos sem alimentação e sem dormir ${ }^{73}$. Podendo mesmo, em alguns casos, estas condutas serem caracterizadas enquanto torturas físicas e, sobretudo, psicológicas. Neste cenário, permaneceu preso no estado do fluminense até agosto de 1974, quando foi posto em liberdade ${ }^{74}$.

Portanto, no contexto das ações repressivas levadas a cabo na zona sul do estado do Rio Grande do Sul, em especial na cidade de Rio Grande-RS, consideramos que muitos dos militares presos sequer sabiam de suas condenações na justiça militar no Rio de Janeiro. Acreditando que a punição já lhes havia sido aplicada quando foram excluídos dos quadros de subalternos da Armada e do Corpo de Fuzileiros Navais. Destarte, foram severas as consequências tanto para os que foram presos,

72 APERS - Processo no 2421-1200/02-3 - p. 4.

73 APERS - Processo no 2421-1200/02-3 - p. 5.

74 APERS - Processo n ${ }^{\circ}$ 2421-1200/02-3 - p.19. quanto para aqueles que se exilaram ou ingressaram na clandestinidade. Deste modo, esses homens tiveram suas vidas consideravelmente desestruturadas - tanto no âmbito profissional quanto no familiar - no mínimo em duas ocasiões, ou seja, quando foram expulsos ou demitidos compulsoriamente da Marinha e quando foram condenados pela justiça militar. Neste contexto, aqueles que foram "apenas" excluídos dos quadros da força naval, sem enfrentar condenações pela justiça militar, como nos casos de Mabel Gonçalves e Paulo Costa. Mesmo estes, enfrentaram grandes dificuldades para retomarem suas vidas em uma cidade como Rio Grande-RS, constantemente vigiada e onde a "operação limpeza" foi conduzida "à toda máquina"” pela instituição que os excluiu de suas fileiras.

Portanto, perseguidos desde 1964, aqueles ex-militares não tiveram muitas escolhas, a não ser, mais uma vez, alterar completamente o curso de suas vidas e enfrentar a "tormenta" que se apresentou na zona sul gaúcha, sobretudo em Rio Grande-RS. E, desse modo, as memórias desses marinheiros tem significativa relevância para a reconstrução de suas trajetórias e da própria AMFNB. Mas, principalmente, para trazer à luz a perspectiva dos "vencidos" nessa disputa, evidenciando as fronteiras de suas identidades enquanto marinheiros naquele contexto tensionado do início dos anos 1960. Pois, na medida em que "a identidade é um produto social, de certa maneira sempre em devir no quadro de uma relação dialógica e temporal" (CATROGA, 2001, p.26) entre sujeitos sociais. Podemos considerar que a memória, enquanto construto social intimamente ligado às três temporalidades da existência humana - passado, presente e futuro - é elemento fundamental nesse processo de construção de identidades e, consequentemente, nas disputas de memórias.

75 Expressão marinheira que, a exemplo de outras como: "a todo pano", "à plena carga" ou "a todo vapor", remete ao significado da plenitude de uma determinada ação ou procedimento. 


\section{Considerações Finais}

Frente ao exposto, na análise das memórias reavivadas, consideramos que a AMFNB se constituiu enquanto instrumento de resistência organizada de caráter coletivo, formada a partir de um processo de identificação por parte dos subalternos. Que se fundamentou na percepção das semelhanças com seus pares e das radicais diferenças no que concerne à oficialidade, em uma relação de dominação e resistência entre os mesmos.

A trajetória da associação "fuzinauta" se construiu a partir da leitura do contexto da época, realizado por seus membros e apoiadores, e da decisão por buscar mudanças e alternativas - em uma instituição total - para uma realidade de intensa fragilidade social, marcada por disputas e demandas constantemente "sufocadas" pelos regulamentos e pela hierarquia militares. Neste sentido, ressaltamos o caráter de resistência da mobilização dos marinheiros e o processo de construção da identidade desses militares na prática das relações sociais estabelecidas internamente à Marinha, especialmente a bordo dos navios.

Dessarte, consideramos que a reconstrução da trajetória desses militares a partir da memória reavivada se constitui enquanto oportunidade para "dar voz" a esse segmento social tão estigmatizado. Possibilitando oportunidades para que se estabeleçam novas disputas de memória, no sentido de que é "a recordação [...] quem dá futuros ao passado, numa atividade de re-presentificação (sic.)" [Grifo do autor] (CATROGA, 2001, p.23) cuja significância reside não somente em demandar um determinado passado a partir de um presente específico e perspectivas de futuro. Mas também em evidenciar as relações sociais a partir das quais se fundamentaram determinados processos de identificação e, consequentemente, os limites de identidades de segmentos sociais específicos, como os marinheiros. Que após um processo de mobilização materializado na fundação da AMFNB em 1962, experienciaram a radicalização do movimento, em um contexto marcado por intensa polarização política e mobilização social. E ainda, uma sistemática repressão desencadeada tanto no Rio de Janeiro-RJ quanto em cidades situadas fora dos grandes centros, como Rio Grande-RS.

Por fim, o presente artigo procurou contribuir para uma melhor compreensão do movimento dos marinheiros de 1962-1964, trazendo à cena a "vOz dos vencidos" no sentido de aprofundar o debate sobre a própria mobilização "fuzinauta", bem como, sobre seus desdobramentos - em especial a repressão - fora das grandes cidades brasileiras. De modo algum pretendemos aqui esgotar o assunto, mas apenas apresentar uma contribuição no que concerne às análises historiográficas acerca deste segmento de militares da Marinha e suas mobilizações, sempre tão marcantes no cenário nacional. Por fim, esperamos ter contribuído para iluminar um período ainda tão nebuloso de nossa história e assim suscitar novos estudos acerca do tema.

\section{Fontes}

\section{Entrevistas:}

"Entrevistado A" (membro da AMFNB) - Entrevista realizada por Edgar Ávila Gandra e Robert Wagner Porto da S. Castro, em 21 de novembro de 2013, nas dependências do Núcleo de História Regional, no Instituto de Ciências Humanas da Universidade Federal de Pelotas, no bairro Centro, cidade de Pelotas-RS.

José Xavier Cortez (uma das lideranças da AMFNB) - Entrevista realizada por Anderson da Silva Almeida, em 22 de dezembro de 2009, no contexto de sua pesquisa de mestrado. Ver: ALMEIDA, Anderson da Silva. Todo leme a bombordo - marinheiros e ditadura civil-militar no Brasil: da Rebelião de 1964 à Anistia. Dissertação (Mestrado em 
História Social) Universidade Federal Fluminense - UFF. Niterói, 2010.

Paulo Fernando da Costa (membro da AMFNB) $-1^{\mathrm{a}}$ Entrevista realizada por Edgar Ávila Gandra e Robert Wagner Porto da S. Castro, em 02 de novembro de 2013, na residência do entrevistado no bairro Cassino, cidade de Rio Grande-RS. $2^{\text {a }}$ Entrevista realizada por Edgar Ávila Gandra e Robert Wagner Porto da S. Castro em 27 de março de 2014, na residência do entrevistado no bairro Cassino, cidade de Rio Grande-RS.

\section{Livros de Memória:}

CAPITANI, Avelino Biden. A rebelião dos marinheiros. Porto Alegre: Artes e Ofícios, 1997.

DUARTE, Antônio. A luta dos marinheiros. Rio de Janeiro: Inverta, 2005.

VIEGAS, Pedro. Trajetória Rebelde. São Paulo: Cortez, 2004.

\section{Arquivos e Bases de Dados:}

Arquivo da União dos Militares NãoAnistiados

Arquivo Público do Estado do Rio Grande do Sul - Comissão Especial de Indenização de ExPresos Políticos do Estado do Rio Grande do Sul

Projeto Brasil Nunca Mais Digital BNMDigit@1 - http://bnmdigital.mpf.mp.br

\section{Legislações:}

BRASIL, Decreto no 6227 de 24 de janeiro de 1944. Código Penal Militar. Disponível em: $\quad<$ http://www2.camara.leg.br/legin/fed/ declei/1940-1949/decreto-lei-6227-24-janeiro1944-417391-publicacaooriginal-65269-pe.html> Acesso em: 16 de out. de 2017.

\section{Periódicos:}

Acervo Digital / Jornal O Globo - Rio de Janeiro, 30 de março de 1964.

\section{Referências}

ALMEIDA, Anderson da Silva. Todo leme a bombordo: marinheiros e ditadura civil-militar no Brasil: da Rebelião de 1964 à Anistia. Dissertação, Mestrado em História Social) Universidade Federal Fluminense, Niterói, 2010.

ALMEIDA, Silvia Capanema P. de. Vidas de marinheiro no Brasil republicano: identidades, corpos e lideranças da revolta de 1910. In: Antíteses. Universidade Estadual de Londrina, PR, Londrina: v. 3, n. esp., pp.90-114, dez. 2010.

BERSTEIN, Serge. A cultura Política. In: RIOX, Jean-Pierre e SIRINELLI, Jean-Franpois. (Org.). Para uma história Cultural. Lisboa: Estampa, 1998.

CASTRO, Robert Wagner Porto da Silva Castro. $\mathrm{Na}$ esteira da memória: A questão social e a mobilização dos marinheiros, atuação e repressão na cidade de Rio Grande-RS (1962-1964). Dissertação, Mestrado em História, Universidade Federal de Pelotas, Pelotas, 2016.

CATROGA, Fernando. Memória, História e Historiografia. Coimbra: Quarteto, 2001.

A representificação do ausente: memória e historiografia. In: Revista Anistia Política e Justiça de Transição, n. 2, jul/dez, Brasília: Ministério da Justiça, 2009.

DIAS, José Carlos; FILHO, José Paulo Cavalcanti; KEHL, Maria Rita; PINHEIRO, Paulo Sérgio; DALLARI, Pedro Bohomoletz de Abreu e CUNHA, Rosa Maria Cardoso da. Relatório da Comissão Nacional da Verdade, v. 1 tomo II e v. 3, Brasília: CNV, 2014.

GANDRA, Edgar Ávila. O cais da resistência. A trajetória do Sindicato dos Trabalhadores nos Serviços Portuários de Rio Grande nos ano de 1959 a 1969. Cruz Alta: UNICRUZ, 1999. 
GOFFMAN, Erving. Manicômios, prisões e conventos. São Paulo: Perspectiva, 1974.

HALBWACHS, Maurice. A memória coletiva. São Paulo: Centauro, 2003.

LUCA, Tania Regina de. História dos, nos e por meio dos periódicos. In: PINSKY, Carla Bassanezi (Org.). Fontes Históricas. São Paulo: Contexto, 2011.

POLLAK, Michel. Memória, Esquecimento, Silêncio. In: Estudos Históricos, Rio de Janeiro, v. 2, n. 3, pp. 3-15, 1989.

REIS, Daniel Aarão. Ditadura e sociedade: as reconstruções da memória. In: REIS, Daniel Aarão; RIDENTI, Marcelo e MOTTA, Rodrigo Patto Sá (Org.). O golpe e a ditadura militar 40 anos depois (1964 - 2004). Bauru: EDUSC, 2004.

RODRIGUES, Flávio Luís. Vozes do mar, o movimento dos marinheiros e o golpe de 1964. São Paulo: Cortez, 2004.

ROLLEMBERG, Denise. Ditadura, intelectuais e sociedade: O Bem-Amado de Dias Gomes. In: AZEVEDO, Cecília; ROLLEMBERG, Denise; KNAUSS, Paulo; BICALHO, Maria Fernanda Baptista e QUADRAT, Samantha Viz (Org.). Cultura política, memória e historiografia. Rio de Janeiro: FGV, 2009.

WOODWARD, Kathryn. Identidade e diferença: uma introdução teórica e conceitual. In: SILVA, Tomaz Tadeu. (Org.) Identidade e diferença: a perspectiva dos estudos culturais. Petrópolis: Vozes, 2014.

Recebido em 30 de novembro de 2017

Aceito em 23 de dezembro de 2017 